\title{
SEJARAH PASTORAL KEUSKUPAN SURABAYA: 1850-1942
}

\author{
Petrus Canisius Edi Laksito \\ STKIP Widya Yuwana \\ edilaksito@widyayuwana.ac.id
}

\begin{abstract}
This article deals with some elements of pastoral works and care of souls in the Diocese of Surabaya, in the East Java, Indonesia, especially in the mission era of 1850-1942. This period, which ends with the defeat of the colonial power of the Dutch by the Japanese occupation forces, is of great importance, because it laid the foundation of the community life of this Diocese for the next periods. Being still in the period of mission, pastoral works of caring the souls of those days were characterized by the atmosphere of mission works. While as a term "mission" was still a "keyword" of this period, it is hoped that a good understanding about this period could be a good introduction for the future study of the history of pastoral works in the Diocese of Surabaya.
\end{abstract}

Keywords: history, pastoral works, mission, the Diocese of Surabaya

\section{PENDAHULUAN}

Istilah "pastoral”, "reksa pastoral” atau "pelayanan pastoral” merupakan istilah yang cukup modern. Istilah ini dipakai untuk berbicara tentang “pemeliharaan jiwa-jiwa”, suatu "pelayanan keselamatan” (Christus Dominus art. 35) yang ditujukan bagi semua orang. Sejarah mencatat bahwa pada mulanya pelayanan pastoral dipandang secara eksklusif sebagai tugas klerus. Hukum Gereja sendiri masih berpegang erat bahwa "pemeliharaan penuh terhadap jiwajiwa” mengandaikan tahbisan imam (Kan. 150). Namun di sisi lain, semakin disadari bahwa tugas pemeliharaan jiwa-jiwa merupakan tugas yang secara hakiki melibatkan semua umat Allah sesuai dengan status hidup dan tugas masingmasing, dalam berbagai bentuk dan tingkatan partisipasi yang berbeda-beda (Schuur, 1975: 359).

Istilah "keuskupan" sendiri menerjemahkan kata Latin dioces (Yun. diokesis), artinya pengelolaan, pengaturan, administrasi, rumah tangga, pemerintahan. Istilah ini oleh Gereja digunakan untuk menyebut satuan administrasi pastoral yang digembalakan oleh seorang uskup. Kitab Hukum Kanonik (KHK) Kan. 369 mengatakan: 
"Keuskupan adalah bagian dari umat AlIah, yang dipercayakan kepada Uskup untuk digembalakan dengan kerjasama para presbiter, sedemikian sehingga dengan mengikuti gembalanya dan dihimpun olehnya dengan Injil serta Ekaristi dalam Roh Kudus, membentuk Gereja partikular, dalam mana sungguh-sungguh terwujud dan berkarya Gereja Kristus yang satu, kudus, Katolik dan apostolik.”

Dengan gagasan tentang pastoral dan prinsip pelaksanaannya yang partisipatif dalam Gereja, serta gagasan tentang keuskupan (dioces) sebagai satuan administrasi pastoral di bawah penggembalaan uskup dibantu oleh para imam dan seluruh umat "dalam mana sungguh-sungguh terwujud dan berkarya Gereja Kristus”, di sini akan dikaji reksa pastoral Keuskupan Surabaya dalam sejarah. Kajian ini mencakup berbagai unsur penataan, pengelolaan dan pelayanan untuk mewujudkan Gereja Kristus dan untuk menjadikan Gereja itu sungguh-sungguh berkarya, sehingga dalam perwujudan dan karya itu penyelamatan jiwa-jiwa seluruh umat dapat terlaksana, sebagaimana dimaksud oleh Kan 369.

Sebagai studi berlatar belakang sejarah, tulisan ini akan mengkaji unsurunsur reksa pastoral atau pemeliharaan jiwa-jiwa pada era misi, hingga berakhirnya kekuasaan kolonial Belanda akibat kedatangan Jepang. Periode ini merupakan periode yang meletakkan landasan bagi kehidupan Gereja Keuskupan Surabaya pada masa-masa selanjutnya. Berbagai unsur pastoral atau pemeliharaan jiwa-jiwa pada periode awal ini masih sangat diwarnai oleh suasana dan semangat misi. Meskipun di sini terminologi "misi” masih menjadi kata kunci, diharapkan pemahaman yang baik mengenai kurun waktu ini dapat menjadi pengantar bagi studi lebih lanjut tentang sejarah karya pastoral di Keuskupan Surabaya.

Selanjutnya, bahan studi ini diharapkan dapat membantu para imam dan petugas pastoral Keuskupan Surabaya lainnya dalam merefleksikan prioritasprioritas pastoral di masa depan. Dengan bahan ini diharapkan bahwa masingmasing imam, sebagai orang yang secara khusus ditahbiskan untuk "pemeliharaan penuh jiwa-jiwa”, maupun rekan-rekan kerja mereka, dapat mengevaluasi diri dan karya pastoral yang dijalankan, agar karya keselamatan Kristus yang diserahkan kepada mereka dapat terlaksana sebaik-baiknya.

\section{PEMBAHASAN}

\subsection{Gereja bagi Semua Golongan Manusia: Visi yang Memimpin}

"Pemeliharaan jiwa-jiwa" di wilayah Hindia-Belanda mula-mula berarti pemeliharaan jiwa-jiwa orang Eropa yang hidup “di seberang laut”. Namun di tahun 1850-an, pada masa kepemimpinan Vikaris Apostolik Mgr. P.M. Vrancken, terjadi pergeseran. Dari reksa pastoral bagi golongan Eropa saja, menjadi pelayanan juga bagi orang-orang "Timur Asing” dan para "Pribumi”. Pada tahun 1850, misalnya, sakramen Krisma di Batavia tidak hanya diterima oleh orang- 
orang Belanda, Belgia, Perancis, Jerman dan Portugis, tetapi juga oleh beberapa orang Melayu, Cina, Afrika, dan seorang pemudi Papua. Pada tahun 1853 di Pulau Bangka dibuka stasi untuk orang-orang Cina yang bekerja sebagai buruh tambang. Pelopornya seorang dokter Cina yang dibaptis di Penang, Malaysia. Selain itu, pada tahun 1851 diadakan penjajagan apakah ada orang-orang Katolik di Kalimantan Barat. Penjajagan yang sama diadakan di Kalimantan Timur pada 1853-1854. Karena hanya terdapat sedikit orang di wilayah itu, temuan-temuan tidak ditindaklanjuti dengan pendirian paroki (Boelaars, 2005: 77).

Sementara itu temuan besar justru terjadi di Flores, wilayah yang sejak akhir abad ke-16 merupakan koloni dan wilayah misi Portugis. Pada tahun 1853, Caspar De Hesselle, pastor muda Belanda yang baru datang pada tahun 1851 dan menjadi kapelan di Surabaya tahun 1851-1852, mengunjungi Larantuka dan mendapati sekitar 3.000 orang Katolik. Meskipun harus menanggung risiko kehilangan gaji sebagai pegawai, pada tahun 1854 De Hesselle memilih pergi ke tanah Batak dan tinggal di sana untuk mempelajari bahasa dan memulai misi. Sayang ia sakit parah, dan meninggal di sana. Karena tak ada penggantinya, maka wilayah itu diserahkan kepada para misionaris Protestan pada 1857. Karena telah diisi oleh misionaris Protestan, misionaris Katolik sesudahnya dilarang masuk ke tanah Batak (Boelaars, 2005: 78).

Dalam hal pengembangan misi itu sendiri, internuntius di negeri Belanda pada tahun 1848 telah meminta tarekat Redemptoris untuk mengirim utusan ke Hindia-Belanda, tetapi tidak berhasil. Mgr. Vrancken ingin memulai semacam seminari, karena suksesnya misi memerlukan klerus pribumi. Tapi tenaga tidak memadai, dan dana hanya dapat diperoleh dari beberapa imam yang berhak menerima gaji berdasarkan izin pemerintah Belanda untuk berkarya di HindiaBelanda, yang biasa disebut "Radikal”. Keharusan adanya izin tersebut muncul karena adanya Peraturan Pemerintah Hindia-Belanda art. 123 tahun 1854, yang kemudian berubah menjadi art. 177 tahun 125 tanpa perubahan isinya. Di situ dikatakan bahwa para pelayan, imam dan misionaris Kristiani dan denominasidenominasi lain diharuskan memiliki izin khusus yang disebut radikaal, agar dapat menjalankan karya mereka di tanah jajahan (Aritonang \& Steenbrink, 2008: 644). Art. 123 tahun 1854 sendiri dibuat untuk menegaskan bahwa kepentingan negeri Belanda di tanah jajahan harus menjadi prioritas, jangan sampai diganggu oleh karya penginjilan (Boelaars, 2005: 75-76).

Setelah permintaan bantuan tahun 1848 gagal diperoleh, akhirnya tahun 1858 Serikat Yesus bersedia memberikan tenaga, yang datang sejak 1859. Kelak, pada tahun 1893 para imam Yesuit mengambil alih seluruh karya Gereja di Hindia-Belanda, yang kini menempatkan misi sebagai tekanan perhatian, dari tangan klerus diosesan. Sementara semua ini berjalan, Flores, yang berdasarkan perjanjian dengan Portugis ditetapkan sebagai wilayah jajahan Belanda pada 
tahun 1851, dan kemudian Timor Barat pada tahun 1859, menjadi kawasan terbesar umat Katolik "Pribumi” di seluruh wilayah Nusantara (Boelaars, 2005: 78-79).

Demikianlah pengembangan Gereja dalam konteks politik Nusantara masa kolonial: bermula dari "visi", yaitu pandangan, keinginan, harapan, untuk menghadirkan iman bagi semua golongan orang. Bukan hanya bagi orang-orang Eropa, melainkan juga bagi orang-orang Timur Asing atau pendatang dan Pribumi yang lebih dahulu tinggal di kepulauan. Yang semuanya kelak membentuk satu bangsa Indonesia. Jika kita berbicara tentang “misi”, dalam konteks ini berarti upaya penerapan visi Gereja yang hadir bagi semua manusia, Gereja yang menjadi milik semua jiwa, apapun golongannya, Dalam situasi ini, ditetapkannya Flores dan sebagian Timor sebagai wilayah koloni Hindia-Belanda menjadi sumbangan yang tersendiri bagai pembentukan Gereja "bagi semua golongan orang” di wilayah Nusantara. Meskipun, memang, masih diperlukan waktu lagi untuk proses integrasi dan pembentukannya menjadi satu Gereja yang mandiri di Negara Kesatuan Republik Indonesia yang merdeka.

\subsection{Kebijakan Pemerintah VS Kebebasan Beragama: Aspek Politik}

Kehadiran imam-imam Katolik di Hindia-Belanda baru terjadi pada tahun 1808, beberapa waktu setelah orang-orang Katolik di Belanda mendapatkan kebebasan beragama di negeri mereka akibat revolusi Perancis dan penguasaan Perancis atas Belanda. Sebelumnya, kalvinismelah satu-satunya agama yang mendapatkan tempat layak di Belanda. Meskipun begitu, Gereja Katolik di Hindia-Belanda masih menghadapi banyak kesulitan, baik karena kebijakan kolonial untuk menjaga ketenangan dan ketertiban (rust en orde), maupun karena masih ada semangat anti-Katolik. Keadaan baru berubah setelah negosiasi panjang Vatikan dan pemerintah Belanda, yang akhirnya disusul dengan kehadiran Mgr. Vrancken pada tahun 1848. Negosiasi ini memperjelas bahwa wewenang memindahkan imam-imam merupakan wewenang Vikaris Apostolik. Juga tak ada pembatasan jumlah tenaga imam yang tidak digaji oleh pemerintah. Hanya, demi rust en orde, kehadiran misi Protestan dan Katolik di satu tempat tidak diperkenankan. Jika ada yang dilanggar, izin berkarya bisa dicabut (Aritonang \& Steenbrink, 2008: 644).

Seperti diketahui, kehadiran imam Katolik di Hindia-Belanda pada mulanya terkait dengan kebutuhan reksa jiwa-jiwa orang Katolik Eropa yang bekerja "di seberang”, entah sebagai pejabat, tentara atau pedagang. Untuk memulai karyanya, mereka harus mendapatkan izin yang disebut "Radikal”. Mereka yang telah memiliki "Radikal" berkedudukan sebagai pegawai dengan pangkat tertentu, diberi gaji oleh pemerintah, dan diharuskan taat pada pejabat di atasnya. Hal yang sudah berlaku biasa bagi pendeta Protestan ini pada gilirannya 
menimbulkan persoalan bagi imam Katolik, khususnya ketika mereka mau menegaskan ajaran Katolik kepada para pengikutnya. Prefek Apostolik yang masuk tahun 1834, Mgr. Y.H. Scholten, harus berurusan dengan Gubernur Jenderal Baud karena mengingatkan umat Katolik untuk tidak menjadi anggota vrijmetselarij atau Freemasonry (Boelaars, 2005: 72-74).

Karena mengingatkan umatnya untuk tidak menjadi anggota vrijmetselarij, Mgr. Scholten tidak diizinkan melakukan perjalanan dinas (atau pastoral) ke luar Jawa. Namun toh pada tahun 1834 dia menjual seluruh perabot rumah untuk biaya ke Padang, menemui sekelompok kecil umat Katolik di sana. Puncaknya, Mgr. Grooff, pengganti Mgr. Scholten yang masuk pada tahun 1845, pada tahun 1846 diperintahkan meninggalkan Hindia-Belanda karena memberikan penugasan kepada imam-imam yang tidak memiliki "Radikal”. Reaksi keras dari umat Katolik di negeri Belanda ikut menjadi pendorong dikeluarkannya "Nota der Punten” tahun 1847. Nota ini menetapkan bahwa wewenang menugaskan, menempatkan dan memindahkan para imam ada pada waligereja, dengan pemberitahuan kepada Gubernur Jenderal berkenaan dengan hak-hak dan gajinya. Sementara itu, pemerintah masih tetap memiliki wewenang mencabut izin imam yang dipandang membahayakan rust en orde. Untuk menegaskan, "Nota” ini kemudian diperkuat dengan art. 123 tahun 1854 (Boelaars, 2005: 74-76).

Dengan latar belakang tarik ulur politik di atas, Gereja di Hindia-Belanda memasuki abad baru, yaitu abad ke-20, yang diwarnai dengan semangat misi kepada orang-orang non-Eropa, baik yang berasal dari golongan Pribumi maupun golongan Timur Asing. Yang perlu dicatat di sini adalah bahwa Gereja di kepulauan Nusantara tidak hadir di suatu tempat yang steril dari persoalan, termasuk persoalan politik. Mgr. Scholten sendiri pada saatnya harus pergi ke Belanda dan Roma agar dapat memperoleh kelonggaran dalam berkarya. Dia juga berhasil mengusahakan naiknya status Prefektur Apostolik Batavia menjadi Vikariat Apostolik Batavia, sehingga penggantinya, Mgr. Grooff, datang sebagai Vikaris Apostolik baru. Meskipun, ternyata, Mgr. Grooff masih harus menghadapi persoalan dalam mengangkat imam-imam yang dikehendakinya. Catatan ini setidaknya mengingatkan bahwa terdapat konteks politik khusus yang tidak dapat diabaikan dalam karya pastoral. Yang harus selalu diusahakan adalah kebebasan dalam mengelola Gereja dan mencukupi kebutuhan pelayanan umat. Dalam hal ini, gembala-gembala tidak dapat berpangku tangan.

\subsection{Ius Commissionis di Wilayah yang Dibagi-Bagi: Arti Tak Tergantikan Tenaga Misi}

Selain Batavia, Semarang dan Surabaya yang sudah menjadi paroki pada masa sebelumnya, juga dibuka paroki di Cirebon pada tahun 1878, Magelang pada tahun 1889, Bogor pada tahun 1889 dan Madiun pada tahun 1897. Paroki- 
paroki ini diperuntukkan bagi orang-orang Eropa dan Indo-Eropa. Namun seiring dengan pengembangan misi di berbagai wilayah Hindia-Belanda di akhir abad ke19 itu, di Jawa pada tahun 1894 di buka paroki pertama bagi orang-orang nonEropa, yaitu di Ambarawa, Muntilan dan Yogyakarta. Terobosan bagi karya misi di tanah Jawa terutama dilakukan oleh Rm. Hoevenaars SJ, dan kemudian Rm. van Lith SJ. Seperti diketahui, para Yesuit mula-mula membantu karya para imam diosesan di bawah Mgr. Vrancken pada tahun 1859. Lambat laun mereka mengambil alih posisi di berbagai tempat, hingga akhirnya pada tahun 1893 kepempinan diserahkan kepada mereka, dengan Mgr. J. Staal SJ sebagai Vikaris Apostolik baru. Selain para imam Yesuit itu, juga datang suster-suster dari kongregasi Ursulin, Fransiskanes dari Huijthuizen, Cinta Kasih dari Tilburg, Societas JMJ, serta Bruder Aloysius di Oudenbosch (Boelaars, 2005: 81-82).

Pertambahan tenaga misi secara meyakinkan pada akhir abad ke-19 dan terlebih pada awal abad ke-20 dimungkinkan karena adanya kebebasan beragama bagi orang-orang Katolik di Belanda, yang diperoleh kembali pada kurun waktu sebelumnya. Tarekat-tarekat religius lama dan baru berdiri kembali, merekrut banyak anggota, yang dipersiapkan untuk tugas di Belanda maupun di daerah misi. Dengan pertambahan ini dimungkinkan membagi-bagi Vikariat Apostolik Batavia menjadi daerah-daerah misi, yang segera ditingkatkan statusnya menjadi prefektur-prefektur ataupun vikariat-vikariat apostolik yang baru. Tarekat-tarekat dapat menyelenggarakan karya misi setelah mengurus ius commissionis, yaitu hak atau kepercayaan mengelola suatu wilayah misi, ke Kongregasi Penyebaran Iman (Propaganda Fide) di Roma. Dengan cara ini, di Jawa, Vikariat Apostolik Batavia dibagi-bagi menjadi Prefektur Apostolik Malang (1927), Surabaya (1928), Purwokerto (1932), Bandung (1932), dan Vikariat Apostolik Semarang (1940). Arah perhatian seluruh Gereja di Hindia-Belanda tidak hanya tertuju kepada orang-orang Katolik Eropa, tetapi terutama pada pengembangan misi bagi orangorang non-Eropa, baik orang-orang Timur asing maupun Pribumi.

Pembagian wilayah Gerejawi dan perkembangan karya misi ini secara garis besar dalam berbagai bidang di seluruh Hindia-Belanda sampai tahun 1940 disertai data statistik dapat dilihat pada karya Boelaars (Boelaars, 2005: 85-103). Dengan data itu, setidaknya secara garis besar dapat terlihat adanya perubahan mendasar di wilayah jajahan ini dalam hal kehadiran Gereja dalam kurun waktu hampir setengah abad. Ada harapan bahwa visi Gereja bagi semua golongan manusia dapat terwujud dengan kehadiran tenaga-tenaga misi dalam jumlah luar biasa besar, yang tersebar di seluruh wilayah kepulauan tersebut.

Dalam skema semacam inilah hadir 5 misionaris CM pertama di Surabaya pada tahun 1923, untuk menangani Karesidenan Surabaya, Kediri dan Rembang. Pada tahun 1928 wilayah ini ditetapkan sebagai Prefektur Apostolik, dengan tambahan wilayah Karesidenan Madiun. Setiap tahun jumlah misionaris terus 
bertambah. Sampai dengan tahun 1939, telah datang 39 misionaris CM, dikurangi 2 orang meninggal dan 1 orang kembali ke Belanda karena sakit, yakni Mgr. de Backere sendiri, Prefek Apostolik Surabaya. Selain itu para religius dari berbagai tarekat ikut ambil bagian. Selain bruder-bruder Aloysius dan suster-suster Ursulin yang sudah tiba lebih dahulu, juga terdapat suster-suster SSpS dan PK, serta bruder-bruder BHK. Tentu juga harus ditambahkan dalam karya ini para guru awam, baik yang berkebangsaan Belanda, Tionghoa maupun Jawa yang berkarya di sekolah-sekolah Katolik, yang jumlahnya pasti jauh lebih banyak daripada jumlah imam dan religius.

Karya misi menempatkan sekolah-sekolah sebagai ujung tombaknya, dan guru-guru sebagai pelopor dalam berinteraksi dengan siswa-siswi dan masyarakat untuk mengenalkan kehidupan dan iman Katolik serta Gereja. Dengan status sebagai wilayah misi yang ditangani oleh suatu tarekat tersendiri, Prefektur Apostolik Surabaya berkembang menjadi kawasan misi yang dinamis karena banyaknya sekolah-sekolah misi yang didirikan. Di daerah Blitar yang menjadi pusat misi, misalnya, pada tahun 1935 atau 10 tahun setelah kedatangan para misionaris, telah terdapat 30 sekolah, selain 6 gereja. Adanya gereja di daerah perkebunan dan pedesaan, yaitu di Gabru, Genjong, Ngeni, Sumberboto dan Wonodadi, selain gereja induk di Blitar, menandakan bahwa karya yang dinamis ini memang tengah diarahkan kepada orang-orang Pribumi, selain kepada orangorang Tionghoa dan Eropa sendiri (Laksito, 2005: 87).

Dinamisnya karya misi di wilayah Prefektur Apostolik Surabaya dilengkapi dengan kreativitas bermisi yang orisinal, khususnya dalam bentuk pendirian Gereja bercorak lokal di Puhsarang, Kediri, pada tahun 1937, yang sarat dengan unsur pengajaran melalui konsep bangunan dan ukiran pada dinding. Karya ini melibatkan Ir. Henri Maclain Pont, seorang Katolik taat, arsitek profesional dan arkeolog perintis karya kepurbakalaan di Trowulan. Bekerjasama dengan tenaga awam dan masyarakat setempat, mereka menjadikan Puhsarang suatu laboratorium pewartaan, dilengkapi tonil atau sandiwara yang mengangkat kisah-kisah Kitab Suci, serta bengkel yang memproduksi patung-patung suci dari tanah liat.

Pada kurun waktu itu, jumlah paroki semula 5 buah pada tahun 1928, yaitu Blitar, Kediri dan Madiun, serta Kelahiran Santa Perawan Maria dan Hati Kudus Yesus di Surabaya. Jumlah itu kemudian bertambah menjadi 8 paroki, dengan berdirinya Paroki Cepu pada 1932, Mojokerto pada 1933 dan Kristus Raja Surabaya pada 1936 (Laksito, 2005: 77-78).

Sementara, efektivitas misi di kalangan orang-orang non-Eropa untuk sebagian dapat dilihat dari perbandingan jumlah orang Katolik Eropa dan nonEropa di paroki-paroki tersebut pada tahun 1939. Di Blitar terdapat 476 orang Eropa dan 496 orang non-Eropa. Di Wlingi 72 Eropa dan 125 non-Eropa. Kediri 
572 Eropa dan 308 non-Eropa. Puhsarang 40 Eropa dan 142 non-Eropa. Pare 126 Eropa dan 59 non-Eropa. Madiun 1066 Eropa dan 505 non-Eropa. Cepu 368 Eropa dan 237 non-Eropa. Mojokerto 826 Eropa dan 119 non-Eropa. Dan Surabaya 10.700 Eropa dan 2.210 non-Eropa. Total 14.246 Eropa dan 4.201 nonEropa (Laksito, 2005: 89). Dari data di atas sekaligus tampak betapa jumlah umat di Surabaya mendominasi jumlah secara keseluruhan. Lebih dari separo orang Katolik Eropa dan lebih dari separo non-Eropa tinggal di Surabaya. Jika melihat data umat sekarang (Sensus 2016), perbandingan di atas rupanya tetap bertahan dari waktu ke waktu sebagai suatu pola.

Bagi studi kita di sini, hal yang perlu dicatat adalah bahwa dalam situasi politik pemerintahan yang memberi peluang untuk misi namun dengan pembatasan-pembatasan, karya misi di wilayah Prefektur Apostolik Surabaya dapat berlangsung dinamis dan kreatif. Hal ini terjadi karena diberikan kepercayaan penuh untuk mengelola karya misi dalam rupa ius commissionis kepada CM di wilayah ini di satu sisi, dan semangat berkorban serta pengabdian bagi jiwa-jiwa yang berkobar dan tak kenal lelah pada diri para misionaris di sisi yang lain. Dengan kata lain: sistem administrasi misi dan pastoral di satu sisi, dan semangat melayani jiwa-jiwa di sisi lain. Sekaligus juga layak untuk dicatat di sini keterlibatan semua tenaga misi yang lain: bruder, suster dan kaum awam, khususnya para guru dari berbagai daerah, terutama Jawa Tengah (Muntilan dan Mendut), yang berkarya di sekolah-sekolah. Bahkan juga para baptisan baru kiranya layak disebut karena tentu mereka ikut serta dalam karya Gereja yang masih sangat muda ini untuk mewartakan Injil dan memenuhi kerinduan jiwa akan Kristus, Penyelamat, kepada sesama di sekitar mereka. Kisah tentang para baptisan baru yang diutus untuk menjadi pewarta iman kepada warga sekitar di Puhsarang kiranya menjadi contoh jelas bahwa karya misi ini merupakan karya seluruh umat Allah.

Dengan gambaran di atas, kiranya arti misi dan pastoral di dalam konteks pembahasan kita dapat dipahami lebih jelas. Yaitu bahwa pewartaan Injil dan pemeliharaan jiwa-jiwa sungguh-sungguh terjadi dan terlaksana dengan baik ketika semua tenaga misi dan para pelayan pastoral serta seluruh umat Allah bersatupadu mewartakan Injil keselamatan, saling meneguhkan iman dan melayani di dalam kebersamaan, dan ketika buah-buah karya itu tampak di dalam wujud nyata. Misi dan karya ini dalam konteks Prefektur Apostolik Surabaya telah melahirkan suatu Gereja muda, suatu benih kehidupan terdiri dari jiwa-jiwa Kristiani warga setempat, yang siap ditanam di tanah yang baru di Karesidenan Surabaya, Kediri, Madiun dan Rembang, untuk kelak berkembang menjadi pohon kehidupan yang menghasilkan buah yang berkelimpahan. Nilai tak tergantikan pada insan-insan misioner dan pemelihara jiwa-jiwa perintis penanaman Gereja 
(plantatio Ecclesiae) ini tampak dari Gereja muda, yang warganya baru ribuan, namun bersemangat dan mampu memberikan harapan.

\subsection{Pengembangan Sekolah dan Kring di Blitar: Aspek Organisasi Umat}

Salah satu elemen paling penting dalam pembentukan umat Katolik Pribumi di Jawa Tengah pada masa kolonial dan yang bertahan serta berkembang menjadi bagian utuh dalam sistem pastoral umat sekarang adalah sistem lingkungan, yang dahulu disebut kring (Bld., berarti “lingkaran”, Ing. circle). Dalam sistem kring umat dibagi ke dalam kelompok-kelompok kecil berdasarkan tempat tinggal yang berdekatan. Tiap kring terdiri dari sekitar 20-30 keluarga Katolik. Salah seorang, yang sederhana, berkeluarga dan bertanggung jawab, bertugas sebagai pamong yang berfungsi pastoral, menjalankan tugas penggembalaan bagi kawanan kecilnya yang tinggal di antara orang-orang Jawa lainnya yang menghayati agama Jawa atau Islam. Dia tahu apa yang terjadi di kring-nya, apa yang diperlukan oleh para anggota. Ia membimbing mereka dalam menghadapi keprihatinan dan kebutuhan hidup. Ia memimpin peribadatan dan memberi pelajaran kepada calon baptis. Tiap bulan para pamong bertemu untuk membahas persoalan-persoalan yang berkaitan dengan paroki (Boelaars, 2005: 20-23).

Di Jawa Tengah, sistem kring ini terdapat di paroki Wedi, Ganjuran dan Bintaran. Berkembang terutama di bawah pimpinan imam-imam Jawa pertama, yaitu Hardjosuwondo dan Soegijapranata (Boelaars, 2005: 353). Rm. Soegija sendiri tahun 1934 berinisiatif mengembangkan sistem ini untuk mengorganisasi umat Katolik Jawa di Paroki Bintaran, sebagai paroki yang didirikan untuk orangorang Jawa. Paroki ini terletak kira-kira 400m di sebelah timur Paroki Kidul Loji, yang dikhususkan untuk orang-orang Eropa, yang tidak mengenal sistem kring. Dengan sistem ini, diharapkan "orang Katolik tidak saja berkumpul di gereja pusat, tetapi juga berkumpul di tengah-tengah masyarakat”. Harapan ini muncul dari keyakinan bahwa Gereja tidak mungkin hidup dan berkembang kalau tidak hadir di tengah-tengah masyarakat (Katolik, 2013).

Meskipun sistem kring lahir di Jawa Tengah, yang saat itu berada di bawah Vikariat Apostolik Batavia, dengan pelopor para imam Jawa di sana, namun sistem atau istilah kring ini tidak asing di wilayah Prefektur Apostolik Surabaya. Sebuah tulisan Wiwitane Stasi Blitar yang disusun oleh Agustinus Sarbini Martosoedarma, lulusan Muntilan yang datang pada tahun 1928, mengisahkan kronologi perkembangan Gereja Katolik di Blitar dan sekitarnya pada tahun 1925-1935. Tulisan ini sudah menggunakan istilah kring, meskipun diterapkan dalam konteks khusus, dalam kerangka pengembangan sekolahsekolah Yayasan Johannes Gabriel, karena itu digunakan istilah schoolkring (“kring sekolah”) (Laksito, 2005: 83-85). 
Sebagai kelompok kecil, schoolkring merupakan perkumpulan atas dasar teritorial yang bertugas memberi perhatian pada kehidupan sekolah-sekolah yang ada di wilayahnya. Pertemuan kring diadakan sebulan sekali, hasilnya dilaporkan kepada pemimpin konferensi. Kring Blitar (kota) meliputi volkschool, vervolgschool dan meijesschool Sukorejo, Turi, Tanjungsari, Sekardangan, Blimbing, Karangjati, meijesschool Kepanjenkidul, meijesschool dan vervolgschool Bendogerit. Kring Wlingi meliputi volkschool Sanggrahan, Genjong, Cupon. Kring Nglegok meliputi volkschool Penataran, Karangnongko, Menjangankalung. Kring Kidulan meliputi volkschool Ngeni, Sumberboto, Jemblong, Pasiraman, Tambak dan vervolgschool Suruhwadang. Kring Wonodadi meliputi vervolgschool Wonodadi, kopschool Melania, volkschool Pikatan, Jati, Rejosari dan Kebonagung. Dalam kenyataannya, kring-kring ini tidak hanya berfokus pada urusan persekolahan, tapi memberi perhatian pada perkembangan Gereja secara keseluruhan. Sebagai contoh, Kring Blitar memiliki 17 centrum yang berfungsi sebagai pusat kegiatan, termasuk pelajaran agama, yang melibatkan para warga kring (Laksito, 2005: 85-86). Tentu dapat diperkirakan bahwa yang digunakan sebagai centrum di sini terutama adalah sekolah-sekolah yang terdapat dalam kring tersebut.

Dengan data di atas, pandangan bahwa kring merupakan sistem organisasi umat Pribumi asli Jawa Tengah yang muncul pada tahun 1934 atas inisiatif Rm. Soegija, kiranya tetap dapat diterima. Namun di sisi lain terdapat fakta bahwa pada tahun 1935 juga terdapat struktur kring di Blitar dan sekitarnya yang menjadi wilayah misi, dalam bentuk yang khusus berupa schoolkring, dengan fokus perhatian pada sekolah-sekolah yang ada dalam kring tersebut. Dalam kring tersebut pembinaan umat juga menjadi perhatian, dan dilaksanakan terutama di sekolah-sekolah sebagai centrum-centrum kegiatan. Dan tentu dapat dibayangkan bahwa sebagian tokoh dalam kring-kring tersebut adalah guru-guru yang berkarya di sekolah, yang didatangkan secara khusus untuk turut mewartakan Injil melalui dunia pendidikan.

Para guru yang merintis kring-kring tersebut di lingkungan orang-orang Jawa tentulah guru-guru Johannes Gabriel, yang sebagian besar berasal dari Jawa Tengah, yaitu Muntilan dan Mendut. Bagi guru-guru ini figur Rm. Soegija, yang memperkenalkan sistem kring di Paroki Bintaran, tentu bukan figur asing, melainkan senior mereka dalam pembinaan di Muntilan, dan romo Pribumi yang mereka hormati. Rm. Soegija sendiri pernah berkunjung ke Blitar pada tahun 1932 bersama dengan Rm. Sukiman SJ untuk memberikan retret kepada para guru dan umat yang tinggal di daerah Blitar, Kediri, Wlingi dan Tulungagung (Laksito, 2005: 85-86). Dan lagi antara Gereja di Jawa Tengah dan Jawa Timur sendiri pada dasarnya terdapat hubungan erat, karena secara gerejawi seluruh wilayah Jawa pada masa itu, termasuk Jawa Tengah dan Jawa Timur, berada dalam wilayah 
Vikariat Apostolik Batavia. Para misionaris CM pertama, sebelum tiba untuk pertama kalinya di Surabaya dari Batavia, berkunjung lebih dahulu ke Muntilan untuk menyaksikan pusat misi yang dibangun oleh Rm. van Lith. Dari kunjungan itu mereka terinspirasi untuk membuat karya yang sama, suatu Muntilan di Jawa Timur, yang akhirnya mereka wujudkan di daerah Blitar. Jadi dari kedekatankedekatan ini terlihat bahwa gagasan kring memang merupakan gagasan orisinal untuk mengorganisasi umat dan untuk mendukung karya misi dan pengembangan Gereja. Tidak hanya di Yogyakarta atau di Klaten, atau di Blitar, Wlingi, Kediri dan Tulungagung, tetapi kiranya juga di daerah-daerah lain di Prefektur Apostolik Surabaya, melalui kehadiran para tokoh awam, khususnya guru-guru Jawa. Oleh merekalah kiranya lahir kring-kring dalam Gereja baru yang masih muda itu.

Dengan pendekatan kring terbentuklah "Gereja akar rumput”, terdiri dari kelompok-kelompok kecil umat yang secara teritorial berjejaring membentuk kebersamaan, serta saling menguatkan dalam menghadirkan Gereja di tengah masyarakat di tingkat akar rumput. Dengan sistem kring, pertahanan diri Gereja muda, yang masih berupa benih di tengah masyarakat Jawa, dapat terbentuk. Dengan pola ini gagasan "persekutuan" yang membingkai eklesiologi Konsili Vatikan II, terutama dalam hidup sehari-hari umat, mendapat wajahnya yang khas sejak sebelum Konsili diumumkan. Jika sampai sekarang Gereja Katolik di Jawa atau di Indonesia pada umumnya, termasuk di Keuskupan Surabaya, yang kecil dari segi jumlah, dapat hidup dan diterima baik oleh masyarakat, tentu antara lain karena berfungsinya sistem "kelompok kecil umat" di tingkat akar rumput yang disebut kring atau lingkungan. Di sini umat mengorganisasi diri, membangun hidup dan berkontribusi bagi sesama.

\subsection{Orang Jawa Masuk Katolik: Penyelenggaraan Ilahi}

Visi “Gereja bagi semua golongan manusia” oleh para misionaris CM pertama secara khusus direalisasikan di daerah Blitar. Untuk itu, setelah mendirikan Paroki Kediri pada tahun 1925, mereka mendirikan Paroki Blitar pada tahun 1928. Kediri sendiri, sebelum mereka datang, merupakan stasi yang dilayani dari Madiun. Dengan kedatangan mereka, seluruh wilayah Karesidenan Kediri, meliputi daerah sekitar Kediri, Tulungagung dan Blitar diserahkan kepada mereka. Maka Stasi Kediri dilepas dari Paroki Madiun. Meskipun Paroki Kediri merupakan paroki pertama yang didirikan oleh romo-romo CM di luar Surabaya, bahkan paroki pertama yang mereka dirikan setelah tiba di tanah misi, dan karena itu diberi nama Paroki St. Vincentius a Paulo, namun Paroki Blitarlah sesungguhnya yang dibayangkan sebagai mahkota misi. Kediri sendiri oleh mereka dimaksudkan sebagai pos, sebelum mereka dapat menjangkau Blitar dan mengembangkan misi di sana. 
Pada tahun 1939, menurut data yang diungkap sebelumnya (lihat Bagian IV di atas), di Blitar terdapat 476 orang Katolik Eropa dan 496 non-Eropa. Sementara di Wlingi, satelitnya, terdapat 72 orang Katolik Eropa dan 125 Katolik non-Eropa. Total perbandingannya adalah 548 Katolik Eropa dan 621 Katolik non-Eropa. Dari data ini tampak bahwa di Blitar secara keseluruhan jumlah orang Katolik non-Eropa, yang diandaikan merupakan hasil karya misi, telah melampaui jumlah orang Katolik Eropa. Data ini tidak dijumpai di wilayah-wilayah lain di Prefektur Apostolik Surabaya. Jika jumlah umat Katolik non-Eropa di luar Surabaya diurutkan sesuai dengan jumlah tertinggi, maka urutan pertama adalah Blitar (dengan Wlingi) dengan jumlah 621 jiwa. Selanjutnya adalah Kediri 509 jiwa (yaitu Kediri 308 jiwa, ditambah Puhsarang 142 jiwa dan dan Pare 59 jiwa), Madiun 505 jiwa, Cepu 237 jiwa dan Mojokerto 119 jiwa. Total orang Katolik non-Eropa di luar Surabaya sebesar 1.991 jiwa (Laksito, 2005: 89).

Data di atas membuktikan bahwa karya misi di luar Surabaya telah membuahkan hasil, meski belum terlalu besar. Dapat diperkirakan bahwa pendekatan lewat sekolah paling banyak berperan. Jumlah sekolah di seluruh Prefektur sendiri tahun 1939 sebesar 105 buah. Dari jumlah tersebut, 68 sekolah merupakan sekolah rakyat, yang pastilah dikhususkan untuk anak-anak Pribumi, yang tersebar hingga pelosok. Selain itu terdapat 37 sekolah Eropa atau disetarakan dengannya. Di Surabaya terdapat 16 sekolah, yaitu 9 Europeesche Lagere School (ELS, Sekolah Dasar untuk orang Eropa), 3 HollandschInlandsche School (HIS, Sekolah Dasar Belanda untuk Pribumi), 1 Schakelschool (Sekolah Penghubung, untuk penyetarakan dengan HIS) dan 1 HollandschChineesche School (HCS, Sekolah Dasar Belanda untuk orang Tionghoa); 1 Meer Uitgebreid Lager Onderwijs (MULO, Sekolah Dasar Lanjutan, setara SMP), 3 Vakschool (Sekolah Kejuruan), dan 3 Hogereburgerschool (HBS, Sekolah Menengah). Di luar Surabaya terdapat 4 ELS (1 di Blitar, 1 di Kediri, 2 di Madiun), 4 HIS (1 di Blitar, 1 di Kediri, 2 di Madiun), 6 HCS (Blitar, Kediri, Pare, Kertosono, Mojokerto, Madiun), 1 Vakschool (Blitar), dan 1 Schakelschool (Wlingi) (Laksito, 2005: 115-119).

Dari data ini tampak bahwa di luar 7 sekolah lanjutan dan kejuruan (1 MULO, 3 HBS dan 4 vakschool), hanya terdapat 9 sekolah untuk anak-anak Eropa di Surabaya dan 4 sekolah yang sama di luar Surabaya. Selebihnya, yaitu 68 sekolah rakyat serta 7 HIS, 7 HCS dan 2 Schakelschool yang tersebar di seluruh Prefektur Apostolik Surabaya ditujukan bagi orang-orang non-Eropa, yaitu Pribumi dan Tionghoa sebagai sasaran misi.

Dari segi strategi misi, karya persekolahan kiranya paling stabil menyumbangkan peran. Namun diperlukan banyak waktu untuk mencerdaskan anak-anak dengan pendidikan, dan memperkenalkan kekatolikan. Juga dibutuhkan biaya besar karena harus menyediakan guru yang berkualitas dan sarana-prasarana 
memadai. Rm. J. van Mensvoort CM memberikan lukisan tentang karya persekolahan di Blitar dari segi efektivitas misi untuk mendapatkan baptisan:

"Dari kira-kira 30 sekolah, yang tahap demi tahap menghubungkan penduduk dan setiap tahun membuahkan hasil sedikit dalam bentuk beberapa permandian, jumlah tersebut tidak pernah besar. Dan bahkan sering terjadi bahwa salah satu sekolah, setelah berdiri setahun atau lebih, tidak menghasilkan buah sama sekali” (Laksito, 2005: 142).

Dari gambaran di atas tampak bahwa jalannya suatu karya penyelamatan jiwa-jiwa bisa terasa lambat, tanpa hasil yang tampak luar biasa. Meski dari tahun ke jumlah orang beriman bertambah, namun pertambahan sedikit, hasil biasabiasa, bisa terasa seperti hidup di padang gersang. Namun di sisi lain, providentia Dei, penyelenggaraan Allah, harus menjadi perspektif. Ia mengatakan:

"Saya dapat menjamin Anda, bahwa merupakan keyakinan setiap misionaris yang jujur, bahwa uang, betapapun juga sangat dibutuhkan, tidak merupakan hal yang paling penting, tetapi doa dan pengorbananlah. Setiap misionaris menghadapi pertobatan, di mana 'uang' tidak dapat membantu, di mana penjelasan manusiawi tidak dapat ditemukan, dan dia hanya dapat berkata: 'Digitus Dei est hic', 'Di sinilah letak tangan Tuhan’. Inilah menurut saya hal yang terjadi pada pertobatan di Desa Sumber” (Laksito, 2005: 141142).

Di sini Rm. van Mensvoort berbicara tentang salah satu unsur yang bekerja dalam penyelamatan jiwa-jiwa, bahkan unsur yang utama, yaitu tangan Allah sendiri yang bekerja:

"Ketika Musa di padang gurun memukul karang, dia ragu, namun demikian tersemburlah air secara melimpah, cukup untuk melepaskan dahaga Israel. Apalagi, bila kita dengan penuh iman memukul karang kekafiran dan Islam dengan tongkat doa dan pengurbanan, akan terjadi gelombang pertobatan” (Laksito, 2005: 141).

Jadi rupanya ketika strategi karya telah dipilih dan langkah-langkah perwujudannya dilaksanakan, maka harus dipercaya bahwa hasil positif akan muncul sebagai buahnya. Seiring keyakinan misioner memilih pendidikan sebagai cara mengenalkan Gereja kepada semua golongan manusia, demikian kiranya Tuhan menganugerahkan putera-puteri Gereja yang lahir dari karya yang tekun diperjuangkan dengan cara-Nya.

Justru di Desa Sumber, wilayah Slorok, tidak ada sekolah misi. Tak pernah ada imam berkunjung. Tetapi dari desa ini datang 3 orang ke pasturan Blitar, meminta agar salah satu imam datang dan bercerita tentang iman Katolik. Maka selanjutnya setiap minggu datanglah imam, dibantu oleh guru HIS Johannes 
Gabriel yang memberi pelajaran agama dalam bahasa Jawa, kepada sekelompok besar orang, laki-laki dan perempuan, yang ingin berguru kebatinan. Masa katekumenat berlangsung hampir 2 tahun. Pada akhir 1942, saat Jepang sudah masuk wilayah Blitar, mereka menerima pembaptisan. Baptisan pertama pada tanggal 24 Desember 1942 sebanyak 41 orang, serta baptisan kedua dan ketiga pada tanggal 29 Desember 1942, masing-masing 31 dan 25 orang. Seluruhnya berjumlah 97 orang. Jumlah ini merupakan jumlah terbesar sejak langkah pertama, yaitu pendirian HIS Johannes Gabriel di Blitar tahun 1926. Ketika para misionaris datang kembali dari kamp interniran, mereka mendapati jemaat ini tidak berkurang. Pada tahun 1950, jumlah mereka telah mencapai sekitar 150 orang (Laksito, 2005: 140-141.143).

Jadi penyelamatan jiwa-jiwa, yang membutuhkan usaha keras para utusan Kristus, tak pernah lepas dari perhatian dan tangan Allah sendiri yang bekerja dengan cara-Nya. Barangkali pekerjaan sehari-hari terasa rutin, melelahkan, tak banyak hasil yang nampak. Namun ada saat di mana para penuai mendapatkan panenan melimpah, di luar harapan dan perkiraan. Bahkan sayangnya, demikian melimpah panenan itu sehingga di luar kemampuan para pekerja untuk memelihara dan membudidayakan hasil panen.

Kondisi seperti ini kiranya tercermin pada perkembangan kelak, di kisaran tahun 1965-1970, yang mencatat adanya jumlah baptisan yang melonjak tinggi di Keuskupan Surabaya. Secara keseluruhan, pada tahun 1965-1966 terdapat 2.010 baptisan baru. Pada tahun 1966-1967 terdapat 2.777 baptisan baru. Pada tahun 1967-1968 terdapat 4.276 baptisan baru. Pada tahun 1968 (sebagai puncak) terdapat 6.035 baptisan baru. Pada tahun 1969 terdapat 4.155 baptisan baru. Pada tahun 1970 terdapat 4.175 baptisan baru. Pada tahun 1971 terdapat 2.660 baptisan baru (Laksito, 2005: 196).

Lonjakan ini kiranya merupakan cara Tuhan membesarkan Gereja yang masih muda dan sempat mengalami kehancuran, dan baru bangun kembali dari kehancuran yang diakibatkan oleh pendudukan Jepang dan Revolusi itu. Namun, antara lain karena keterbatasan tenaga, tidak semua jiwa yang telah diperoleh dapat terpelihara dengan baik. Tahun 1995, saat penulis bertugas sebagai diakon di Paroki Pare, ada cerita bahwa ada satu-dua desa yang pada kisaran tahun itu mayoritas penduduknya masuk Katolik, namun kemudian terlepas dari penggembalaan karena kurangnya tenaga yang melayani mereka.

Meskipun kadang karya misi atau pastoral tidak membawa hasil, mengalami kerugian yang fundamental dan menyesakkan, bagaimanapun kita dapat belajar bahwa di luar rencana dan kemampuan manusia, Tuhan mengerjakan karya-Nya. Hilangnya begitu banyak aset Gereja setelah pendudukan Jepang, atau habisnya hampir seluruh orang Katolik Eropa dari data statistik karena konflik Indonesia-Belanda di tahun 1960-an, tidak berarti membuat nafas hidup Gereja 
terhenti. Seperti juga halnya diambilnya semua imam, bruder, suster dan awam Belanda saat pendudukan Jepang dari tengah-tengah umat yang baru tumbuh, ternyata tidak mematikan iman dan jaringan persekutuan, yang telah tersusun berbasis sistem kring. Jadi lagi-lagi, “jari Tuhan”, “tangan-Nya” sendirilah yang melahirkan dan menjaga Gereja.

\subsection{Jemaat yang Kompleks di Surabaya: Organisasi Karya Pastoral}

Di Kota Surabaya, menurut statistik tahun 1917, terdapat 4.602 orang Katolik Eropa. Pada tahun 1935, jumlah itu bertambah lebih dari 2 kali lipat, menjadi 10.636 orang. Pada tahun 1939, jumlah sedikit saja bergeser menjadi 10.700 orang. Artinya, sudah tidak banyak pertambahan. Sementara itu jumlah umat Katolik non-Eropa pada tahun 1921 hanya sebesar 35 orang. Pada tahun 1935, atau 14 tahun kemudian, jumlah ini telah mencapai 1.010 orang. Pada tahun 1939 terdapat 2.210 orang. Pertambahan ini kiranya cukup mengesankan. Bagi kita, tercapainya angka di atas, yaitu 10.700 orang Katolik Eropa dan 2.210 orang Katolik non-Eropa, atau total 12.910 orang, kiranya memberi gambaran tentang adanya dinamika tertentu dalam kehidupan umat Katolik di Kota Surabaya. Tidak seperti daerah-daerah lain di seluruh prefektur, kehidupan umat Katolik di Surabaya ini, sebagai satu jemaat, pada tahun 1939 telah berkembang menjadi suatu kehidupan yang cukup kompleks (Laksito, 2005: 103-104).

Menurut data tahun 1941, terdapat 3 HIS (SD berbahasa Belanda untuk Pribumi), 1 Schakelschool (sekolah penyetaraan dengan HIS) dan 1 HCS (SD berbahasa Belanda untuk orang Tionghoa). Data ini bisa menjadi petunjuk untuk memahami pertambahan umat non-Eropa di kota ini, khususnya dari segi usaha misi mempertemukan masyarakat dengan kekatolikan. Sebagaimana dilaporkan oleh Rm. Klooster CM, karya misi di antara penduduk asli Surabaya berjalan lambat karena amat sedikitnya sarana untuk berjumpa secara langsung dengan mereka. Saat laporan itu ditulis pada tahun 1939, di seluruh Kota Surabaya hanya terdapat 2 HIS dan 1 Schakelschool bagi orang Jawa, serta 1 sekolah kecil dengan sentuhan pendidikan Jawa. "Seandainya kita punya lebih banyak sekolah!" katanya. Dalam kerangka itu dijelaskannya rencana dukungan Missiefonds bagi 1 HIS baru di Kepanjen (Klooster, 1939: 345).

Rm. Klooster CM, pengelola Dana Misi (Missiefonds stichting), yaitu yayasan untuk mendukung karya misi di antara penduduk Pribumi, saat berkarya di Paroki Hati Kudus, Surabaya tahun 1939 itu mengatakan bahwa di Surabaya terdapat 700 lebih orang Katolik Jawa. Jumlah yang tidak besar dibandingkan dengan keseluruhan penduduk Pribumi di Surabaya yang menurut statistik Desember 1937 berjumlah 294.000 jiwa. Menurut hitungan Rm. Klooster, itu berarti hanya 0,25\% saja dari keseluruhan orang Pribumi yang ada di Surabaya. Dalam pengamatannya, kebanyakan orang Katolik Jawa di Surabaya adalah 
orang-orang Katolik "impor”, yang datang dari berbagai daerah di Prefektur Apostolik Malang, Surabaya, Purwokerto, dan dari Vikariat Apostolik Batavia, khususnya Jawa Tengah, sebagai daerah misi romo-romo Yesuit. Orang-orang Jawa Katolik yang sangat sedikit itu, menurut Rm. Klooster CM, kebanyakan berasal dari kalangan bawah. Mereka bekerja antara lain sebagai pembantu rumah tangga (baboe), pesuruh (jongos), pegawai rendahan di kantor-kantor, penjaga keamanan, petugas trem, pelaut, tukang, montir dan seterusnya. Sementara sebagian lagi berasal dari kelas menengah atas atau priyayi. Mereka bekerja sebagai guru, kepala sekolah dan kepala pegawai di kantor tertentu. Tidak ada yang bekerja sebagai pedagang (Klooster, 1939: 344-345).

Dengan uraian yang cukup gamblang di atas, bagi kita asal-usul orang Katolik Jawa di Kota Surabaya menjadi jelas. Selain faktor perjumpaan antara warga asli Surabaya dengan kekatolikan melalui dunia pendidikan, yang terasa lambat, terdapat faktor lain yang mempercepat jumlah mereka, yaitu mobilitas karena pencarian kerja ke Surabaya.

Selanjutnya, jika jumlah seluruh orang Katolik non-Eropa di Surabaya sebesar 2.210 orang dikurangi jumlah orang Katolik Jawa sebesar 700 orang, maka muncul selisih 1.510 jiwa. Selain orang-orang Flores, yang oleh Rm. Klooster disebut tanpa membahas jumlah mereka (Klooster, 1939: 345), dapat diperkirakan bahwa sebagian besar dari antara orang Katolik non-Eropa dalam statistik di atas kiranya terdiri dari orang-orang Tionghoa. Karena jumlah sekolah yang dimaksudkan untuk memperkenalkan kekatolikan kepada orang Tionghoa di Surabaya hanya 1 saja, yaitu sebuah HCS, maka banyaknya orang Katolik dari kalangan ini kiranya tidak diperoleh hanya melalui karya sekolah ini. Dapat juga diduga, mayoritas orang-orang Katolik Tionghoa di Surabaya merupakan pendatang yang berburu nasib di Surabaya.

Namun selain kedua faktor di atas, jelas ada data bahwa terdapat aktivitas misi di luar sekolah kepada masyarakat Tionghoa yang telah menjadi penduduk Kota Surabaya. Harian Katolik Hindia-Belanda, De Koerier, dalam terbitan tanggal 3 Januari 1933 melaporkan sebuah kejadian yang menggambarkan adanya aktivitas semacam ini:

"Sebagai harapan yang menggembirakan adalah kenyataan bahwa lebih banyak orang Cina datang meminta pelajaran agama. Ini adalah karya rahmat Tuhan secara diam-diam, tetapi mungkin juga suatu akibat dari kekecewaan yang mereka alami di lingkungan mereka, sebagai akibat dari kebodohan yang dilakukan oleh gerakan Pentekosta dan sejenisnya. Gunung-gunung mujizat yang menjanjikan dan memberikan sesuatu yang tak bisa diraba ternyata tak lain daripada gejala-gejala histeri dan sulap. Itulah yang mendorong orang-orang dan juga orang-orang Cina kepada keheranan dan keinginan untuk mencari di tempat lain dan yang lebih bagus" (Laksito, 2005: 108). 
Berita di atas berbicara tentang gerakan Pentekosta "pemberi harapan palsu” dengan janji-janji mujizat yang nyatanya hanya berupa histeria dan sulap belaka bagi sejumlah orang Tionghoa. Sekaligus hal ini menjadi bukti rasionalitas dan pragmatisme masyarakat Tionghoa dalam hal keagamaan, yang membutuhkan perhatian yang berbeda dan sikap tersendiri dalam konteks dan kerangka misi. Mgr. de Backere sendiri berbicara tentang orang-orang Tionghoa di Prefektur Apostolik Surabaya yang dikenalnya, dalam konteks yang lebih luas:

"Banyak pentobatan di antara orang-orang Cina. Semakin hari jumlahnya semakin bertambah. Ini gejala yang menggembirakan. Karena paling tidak orang-orang Cina di Prefektur Apostolik Surabaya umumnya orang-orang terpelajar. Dalam masyarakat Indonesia, mereka menempati posisi-posisi penting. Lewat jalan itu ternyata Penyelenggaraan Ilahi telah mengundang para misionaris dan mengantarnya ke panenan jiwa melimpah... Api penetrasi misi terhadap orang-orang Cina telah dinyalakan, dan tanpa ragu api itu akan berkobar besar" (Laksito, 2005: 109).

Merujuk pada karakter demografi masyarakat Tionghoa di HindiaBelanda, kiranya pernyataan Mgr. de Backere lebih merujuk pada kalangan peranakan, bukan kalangan totok. Kalangan totok masih mempunyai hubungan erat dengan tanah leluhur. Sedangkan kalangan peranakan umumnya sudah lama terpisah dari negeri asal, bahkan kebanyakan belum pernah pergi ke Cina. Mereka lebih mudah berakulturasi dengan masyarakat sekitar, entah dari kalangan Belanda atau Pribumi. Selain terbuka pada kebudayaan Jawa, mereka juga terbiasa dengan budaya Barat karena faktor perdagangan, politik, pendidikan ataupun kemasyarakatan pada umumnya. Mereka cenderung menggunakan bahasa Belanda, Melayu atau Jawa, dengan sedikit kata-kata Tionghoa. Kiranya mereka inilah yang lebih terbuka pada kegiatan misi (Laksito, 2005: 107).

Jika diandaikan bahwa telah banyak dari kalangan peranakan ini yang bersentuhan dengan bahasa dan kebudayaan Belanda melalui sekolah-sekolah berbahasa Belanda, yaitu HCS dan sekolah-sekolah lanjutannya, sebelum para misionaris CM tiba di Surabaya dan mendirikan HCS untuk mereka, dapat diperkirakan bahwa dari kalangan inilah diperoleh umat Katolik Tionghoa Surabaya, bahkan lebih banyak daripada umat Katolik Jawa. Sepucuk surat dari Julia Han Bwee Hiang Nio, guru HCS Sulung, tertanggal 1 November 1939 kepada Mgr. de Backere yang sudah kembali ke Belanda, memberi informasi tentang beberapa guru, dan siswa-siswi sejumlah 254 orang. Di antara 254 anak itu, 50 anak, atau 1/5 dari jumlah keseluruhan, sudah Katolik (Laksito, 2005: 304). Jumlah sebesar ini kiranya cukup memberi gambaran tentang antusiasme di kalangan anak-anak Tionghoa peranakan untuk menerima pewartaan Injil.

Namun bagaimanapun juga, jumlah terbesar orang Katolik di Surabaya berasal dari kalangan Eropa, yaitu sebanyak 10.700 jiwa. Jumlah ini kira-kira 1/3 
dari jumlah seluruh orang Eropa pada tahun yang sama, yaitu 32.601 jiwa (Laksito, 2005: 304). Dengan jumlah total umat Katolik Eropa dan non-Eropa sebesar 12.910 jiwa, dengan 2 paroki, yaitu Kelahiran Santa Perawan dan Hati Kudus, dan 1 gereja pembantu Kristus Raja, kita sudah bisa berbicara tentang suatu karya pastoral dalam arti yang sesungguhnya, dengan segala kompleksitas hidup di kota bagi suatu jemaat yang sudah kurang lebih mapan. Dan memang rupanya hal itu yang dapat disaksikan dalam kehidupan jemaat Katolik kota Surabaya saat itu, di mana dijumpai adanya upaya pengorganisasian berbagai aspek hidup dan kebutuhan pastoral. Meskipun, tentu tetap ada upaya-upaya misi yang diusahakan di kalangan masyarakat Jawa dan Tionghoa.

Secara fisik, kehadiran Gereja Katolik di Surabaya tampak dari adanya kompleks bangunan berupa gereja, sekolah dan asrama di Kepanjen (Kelahiran Santa Perawan), gereja dan sekolah di Coenboulevard (Hati Kudus), dan gereja dan sekolah di Ketabang (Kristus Raja). Di Ujung, juga terdapat kapel dan wisma angkatan laut Katolik St. Mikael. Selain itu terdapat beberapa gedung atau kompleks gedung Katolik tanpa disertai bangunan gereja paroki, meskipun sebagian darinya ada yang memiliki kapel. Gedung atau kompleks gedung tersebut adalah: kompleks rumah sakit Katolik St. Vincentius a Paulo di Reinierszboulevard (Diponegoro), kompleks sekolah di Stasiun Wonokromo, kompleks sekolah di Prinsesselaan (Tidar), asrama Don Bosco di Sawahan, kompleks sekolah di Gatotan, kompleks sekolah di Darmo, Gedung Federasi Sosial Katolik di Embong Malang, sekolah dan klinik Melania di dekat Ketabang. Kehadiran gedung-gedung ini membuat berbagai kegiatan dan karya berjalan. Dari sudut pastoral, dengan adanya gedung-gedung ini usaha "pemeliharaan jiwajiwa” dapat terfasilitasi dengan lebih baik, rutin atau stabil, dan lebih mudah direncanakan.

Dari sisi tenaga pastoral, pada tahun 1939 di Kota Surabaya bertugas 15 orang imam, 98 orang suster dan 24 orang bruder. Sementara itu di luar Surabaya terdapat 17 imam, 56 suster dan 10 bruder (Laksito, 2005: 111). Dengan data ini tampak bahwa tenaga-tenaga inti dalam pelayanan jiwa-jiwa, dengan berbagai jenis karya, banyak ditemukan di kota Surabaya. Bersama dengan mereka tentu terdapat lebih banyak lagi kaum awam. Tentu bagian terbesar kelompok awam ini berkebangsaan Belanda, tetapi tentu juga terdapat sejumlah orang Tionghoa dan Jawa, termasuk orang-orang non-Katolik, yang turut bekerja di sekitar mereka. Semua orang ini kiranya ikut ambil bagian dalam berbagai karya para misionaris, baik di bidang pendidikan, kesehatan media massa dan berbagai jenis kegiatan profesional lainnya, maupun di bidang pewartaan, peribadatan dan penggembalaan umat, yang lebih bersifat gerejawi.

Kemudian yang patut dicatat juga adalah kehidupan mereka di tengah masyarakat sebagai komunitas Katolik dengan aktivitas dan karya pelayanan, 
yang tersebar di beberapa tempat di Kota Surabaya. Pertama-tama yang patut dicatat tentu saja komunitas paroki-paroki, baik komunitas pastoral maupun paroki sebagai himpunan umat yang bersifat tetap dan memiliki gembala-gembala mereka secara tersendiri. Selanjutnya juga perlu disebutkan komunitas sekolahsekolah Katolik yang tersebar di beberapa tempat, yang setiap hari kerja diwarnai dengan kegiatan-kegiatan di bidang pengajaran dan pendidikan, meski di sini tidak ada data statistiknya secara khusus. Sebagian komunitas sekolah ini dimotori oleh komunitas bruder dan suster, yang terikat dengan cara hidup khusus sebagai biarawan-biarawati. Selain itu, sebagian komunitas ini berasrama, yang menandakan adanya kehidupan yang lebih khusus dalam kekatolikan di antara para murid. Selain asrama putra Don Bosco (Tidar, lalu Sawahan) dan Johannes Gabriel (Wonokromo), juga terdapat asrama putri St. Angela (Donkerstraat 5) dan St. Ursula (Kepanjen). Di samping komunitas yang bergerak di bidang pendidikan juga terdapat komunitas suster-suster yang berkarya di Rumah Sakit Katolik St. Vincentius a Paulo, beserta para dokter, staf medis, administrasi dan pekerja lainnya. Selain membutuhkan pelayanan rohani dan mengadakan kegiatankegiatan keagamaan, komunitas-komunitas ini bersentuhan secara langsung dengan masyarakat.

Warna khas kehidupan Gereja di Kota Surabaya selanjutnya tampak dari organisasi atau perkumpulan kaum awam. Menurut laporan De Koerier tanggal 3 Januari 1933, muncul banyak organisasi Katolik menyusul terbitnya Ensiklik Quadragessimo Anno oleh Paus Pius XII pada tanggal 15 Mei 1931, yang antara lain menganjurkan dibentuknya organisasi-organisasi atau perkumpulanperkumpulan yang secara khusus ditujukan untuk kesejahteraan umum. Dorongan pembentukan organisasi juga muncul akibat krisis ekonomi sejak tahun 1929. Meskipun begitu, beberapa organisasi awam sudah muncul sebelumnya.

Di bidang pendidikan terdapat federasi guru-guru Katolik yang lahir di Surabaya pada 1916 namun berskala Hindia-Belanda, de Katholieke Onderwijzers-Bond. Organisasi ini pada 1932 mengambil inisiatif membentuk suatu organisasi baru yang memayungi beberapa organisasi Katolik, bernama de Katholieke Vakcentrale (Steenbrink, 2007:35-36). Di Surabaya, organisasi payung ini cukup disebut de Katholieke Centrale. Sementara itu, untuk para pekerja kereta api terdapat de R.K. Spoorbond St. Raphael. Untuk para buruh swasta didirikan St. Josefbond. Untuk anggota angkatan laut didirikan perkumpulan St. Kristoforus. Untuk pegawai-pegawai pemerintah dan swasta juga didirikan organisasi tersendiri. Juga perserikatan douane dan pos/telegraf St. Gabriel. Di bidang politik dalam skala Hindia-Belanda terdapat Indische Katholieke Partij (IKP). Di bidang sosial terdapat de Katholieke Sociale Bond (KSB) (Laksito, 2005: 112-113). 
Bagi orang-orang muda, terdapat de Katholieke Jongeren Actie (KJA), yang bergerak di bidang keagamaan, sosial dan politik, serta berfungsi sebagai organisasi payung bagi berbagai perkumpulan orang muda Katolik. Bagi para perempuan muda terdapat de Dames Jongeren vereeniging. Juga terdapat de Katholieke Meisjeswacht. Beberapa perkumpulan ibu-ibu antara lain St. Theresia vereniging dan St. Anna vereeniging. Sebuah perkumpulan ibu-ibu yang berskala Hindia-Belanda bernama St. Melania vereeniging memberikan kursus pembinaan bagi gadis dan wanita pribumi dan mendirikan klinik di Tambaksari. Bagi orang Katolik Jawa terdapat Perkumpulan Politik Katolik Jawa (PPKD), Wanito Katolik (WK), Katolik Wandawa (KW), Palupi Darmo (PD) dan lain-lain (Laksito, 2005: 113).

Selain itu terdapat berbagai kelompok lain seperti Verkenningsgroep St. Joris, Padvinders (pramuka), de Katholieke Voortrekkerstam St. Paulus, St. Aloysius groep. Dalam hal pembinaan dan kerohanian terdapat St. Vincentius Conferentie dan Maria Congregatie. Juga kelompok paduan suara St. Caecilia dan St. Gregorius Magnus. Sementara itu, dalam situasi krisis ekonomi, juga muncul inisiatif pengumpulan dana bagi para imam, yang ditangani oleh Priesterpenning, kebutuhan bea siswa bagi pelajar ditangani oleh R.K. Studiefonds, dan dana bantuan khusus misi oleh Missiefonds stichting.

Dan terakhir, yang tidak kalah penting untuk menghadirkan dinamika kehidupan umat Katolik di Kota Surabaya adalah media komunikasi. Selain harian Katolik de Koerier, yang terbit di Bandung dan beredar di seluruh HindiaBelanda, terdapat buletin mingguan khusus Prefektur Apostolik Surabaya de Katholieke Gids, yang memuat berbagai berita yang perlu diketahui oleh orang Katolik, baik tentang berbagai perkembangan dan karya Gereja, kegiatan organisasi-organisasi, ajaran Gereja mengenai masalah-masalah sosial maupun artikel yang bersifat apologetis. Media ini terbit sejak berdirinya Prefektur Apostolik Surabaya pada 11 November 1928, hingga edisi Maret 1942, saat Jepang sudah berkuasa di Surabaya. Media ini bagi kita menjadi sumber informasi amat penting tentang dinamika kehidupan Gereja di Kota Surabaya maupun di Prefektur Apostolik Surabaya secara umum. Sedangkan pada saat itu, tulisantulisan di dalamnya kiranya berguna untuk membangkitkan jiwa dan semangat kekatolikan di antara umat dan gembala mereka. Luasnya pembaca dapat terlihat dari jumlah oplah yang dicetak, yaitu 3.000 eksemplar pada tahun 1939. Kehidupan umat dalam bidang media pewartaan dan pengembangan iman selanjutnya juga dilengkapi dengan hadirnya toko buku Katolik, Viribus Unitis. Juga oleh organisasi yang bergerak di bidang perbukuan dan perpustakaan Katolik, St. Vincentius Vereneging.

Aneka informasi di atas pada dasarnya memberikan gambaran umum tentang umat Katolik di Kota Surabaya pada saat menjelang berakhirnya 
kekuasaan Belanda di Indonesia, di bawah kepemimpinan Mgr. M. Verhoeks, CM, yang ditunjuk sebagai Prefek Apostolik Surabaya sesuai dekrit Kongregasi de Propaganda Fide pada hari Jumat, 22 Oktober 1937. Tentu data-data tentang berbagai aspek komuniter yang bersifat permulaan di atas menarik untuk digali dan dikaji lebih lanjut. Sementara, di samping komunitas-komunitas parokial dan religius, komunitas karya dan organisasi-organisasi awam, di Kota Surabaya juga terdapat belasan ribu umat Katolik yang tersebar di seluruh kota dalam keluargakeluarga. Tentu di sinipun terdapat berbagai aspek kehidupan yang menarik untuk digali dan dikisahkan. Namun yang penting untuk diberi penekanan saat ini kiranya adalah bahwa kehidupan umat Katolik sebagai Gereja dengan berbagai dimensi pastoralnya yang kompleks dipastikan sudah ada di Kota Surabaya. Upaya pemeliharaan jiwa-jiwa yang diselenggarakan tentu tidak hanya bersifat individual atau spontan, melainkan mengandaikan pengorganisasian dan penyusunan kegiatan yang bersifat publik, terstruktur dan melibatkan bermacam orang dan peran.

\section{KESIMPULAN}

Pembahasan tentang sejarah pastoral Keuskupan Surabaya pada periode paling awal, 1850-1942, memberikan kepada kita gambaran tentang unsur-unsur pokok kehidupan Gereja Katolik yang dinamis di wilayah yang kini menjadi Keuskupan Surabaya. Mulai dari nol, hingga kemudian berkembang menjadi komunitas gerejawi yang memiliki struktur pastoral yang cukup lengkap sebagai suatu Vikariat Apostolik. Sayangnya, periode ini berakhir dengan kedatangan tentara pendudukan Jepang, yang selanjutnya kelak membuat strategi pengembangan Gereja berada di jalur yang berbeda karena perubahan konteks politik.

Kendati demikian, elemen-elemen pokok kehidupan Gereja yang membentuk suatu "pola pastoral" pada periode ini telah dapat diidentifikasi dengan jelas, sehingga dalam studi lebih lanjut kelak, dapat ditelurusi perkembangannya dan perubahan-perubahan yang terjadi padanya. Setidaknya, tercatat sejumlah unsur pokok dalam periode ini.

Pertama, adanya visi tentang suatu kehidupan sosial keagamaan yang bercakupan universal dan menjangkau semua bangsa ke dalam persekutuan. Adanya visi ini menjadi kekuatan yang tidak hanya menggerakkan karya misi, tetapi juga menegaskan tentang hubungan persaudaraan antarmanusia, yang menjadi prinsip pastoral/penggembalaan.

Kedua, karya misi dan upaya pastoral terhadap jiwa-jiwa yang telah beriman Kristiani mengharuskan adanya perhatian pada unsur sosial-politik. Pada ranah ini, terdapat realitas politik yang membatasi kebebasan beragama dan mobilitas atau pergerakan para misionaris. Adanya kenyataan ini mengharuskan 
misi dan karya pastoral dijalankan dengan suatu strategi dan kehati-hatian, namun juga dengan upaya mencari peluang.

Ketiga, perubahan politik, yaitu adanya kebebasan beragama menjadi momentun bagi pengembangan strategi misi. Dalam situasi yang baru, wilayah yang luas dibagi-bagi kedalam wilayah-wilayah misi melibatkan beraneka tarekat religius, sehingga secara luas dan masif berlangsung upaya perjumpaan langsung dengan warga Pribumi atau golongan masyarakat setempat. Kegiatan misi kepada warga setempat berbarengan dengan upaya penggembalaan orang-orang Katolik lama, yaitu orang-orang Eropa, dan orang-orang setempat yang telah menjadi Katolik, dalam suatu pola pastoral yang lebih memadai.

Keempat, komunitas Katolik baru yang terbentuk di wilayah misi juga berperan dalam pengembangan karya misi melalui sistem kolompok-kelompok kecil berbasis setempat. Hal ini dijumpai di Blitar, yang mengembangkan berbagai schoolkring untuk menyokong karya sekolah. Terbentuknya pola ini tentu juga merupakan wujud kebaruan yang bernilai pastoral, karena dengan cara ini umat Katolik baru ini masuk ke dalam suatu "sistem penggembalaan” tertentu, yang di masa depan ternyata menjadi pola pastoral baku di Jawa, bahkan Indonesia.

Kelima, Misi bukan hanya dan bukan pertama-tama "karya manusia", melainkan "karya Allah". Bahkan, dalam kondisi kritis dari kacamata manusia, terbukti nyata bahwa “Allah bekerja”. Hal ini terjadi di Blitar, di mana upaya misi diusahakan melalui pendirian amat banyak sekolah, tetapi pada saat yang diharapkan tidak kunjung menampakkan hasil sebagaimana diharapkan oleh pikiran manusia. Telunjuk Allah bekerja dengan mendatangkan warga baru dalam jumlah besar dari satu desa di Sumber, Slorok.

Keenam, Realitas pastoral yang kompleks, baik dari segi suku bangsa, latar belakang profesi dan kekhasan golongan umat, memunculkan adanya upaya pastoral dalam berbagai bentuk. Itulah yang dijumpai di Surabaya, yang memberi gambaran tentang suatu keharusan menghayati kesatuan yang Katolik dalam penggembalaan di tengah keanekaragaman.

Adanya unsur-unsur pastoral yang dijumpai di atas, pada periode awal Gereja Keuskupan Surabaya, kiranya memberi penegasan tentang pentingnya menyadari adanya aneka macam unsur yang mempengaruhi kehidupan pastoral pada suatu masa. Dengan kesadaran itu, selanjutnya dalam pastoral perlu diberikan perhatian dan upaya kajian terhadap unsur-unsur dalam menyusun karya atau strategi pastoral, agar karya pastoral tidak berjalan sekedar sebagai upaya tanpa arah dan keseriusan, atau upaya sekedarnya.

Para misionaris, yang merintis berdiri dan berkembangnya Gereja Keuskupan Surabaya, dan terlebih orang-orang Katolik dari warga masyarakat setempat, yang terpanggil untuk masuk dalam persekutuan Gereja, dapat menjadi 
model bagi kita untuk memiliki suatu cakrawala yang lebih menyeluruh tentang karya misi dan pastoral terhadap mereka yang telah terpanggil oleh seruan misi. Meskipun pastoral mengharuskan adanya peran klerus yang tak tergantikan, tetapi dalam praktik dalam komunitas di Blitar maupun Surabaya, jelas terlihat dan diandaikan adanya peran para awam di sekeliling mereka. Sehingga pemahaman tentang pastoral yang partisipatif, yang muncul pada saat ini, sesungguhnya sudah dijumpai wujudnya jauh di masa lampau, di awal sejarah Gereja Keuskupan Surabaya.

Selain itu juga tidak kalah pentingnya untuk melihat, siapakah aktor utama dalam karya Gereja, baik yang murni sebagai karya misi, yang bertujuan untuk mencari dan menyelamatkan jiwa-jiwa, atau pastoral sebagai kelanjutan dari karya misi untuk memelihara jiwa-jiwa yang telah beriman. Pastoral, selain mengandalkan adanya visi, strategi, serta kecerdasan mengelola potensi dan sumberdaya, juga perlu disertai kesadaran dasar akan adanya unsur peran dan campur tangan Ilahi, terhadap usaha dan rencana manusia.

\section{DAFTAR PUSTAKA}

Aritonang, Jan Sihar, dan Steenbrink, Karel (eds.)., 2008, A History of Christianity in Indonesia. Leiden: Brill.

Boelaars, Huub J.W.M. OFM Cap., 2005, Indonesianisasi. Dari Gereja Katolik di Indonesia Menjadi Gereja Katolik Indonesia. Yogyakarta: Kanisius.

Laksito, Petrus Canisius Edi., 2005, Mendidik Anak Bangsa. 80 Tahun Geliat dan Pasang Surut Yayasan Yohanes Gabriel Menjadi Indonesia. Surabaya: Yayasan Yohanes Gabriel Keuskupan Surabaya.

Katolik, Pena, 2021, “Mgr. Suharyo: 'Lingkungan’ adalah Ciri Khas Gereja Indonesia”. 2013. Diunduh dari http://penakatolik.com/2013/07/16/mgrsuharyo-lingkungan-adalah-ciri-khas-gereja-indonesia/ pada tanggal 18 September 2021.

Klooster, J. CM, 1939, "Het Missiewerk in Soerabaia”, dalam The Katholieke Gids, 11e Jaargang No. 37, 10 September 1939.

Schuur, Viktor, 1975, "Pastoral Ministry”, dalam Karl Rahner et.al. (eds.), Sacramentum Mundi. An Encyclopedia of Theology, Vol. III. Bangalore: Theological Publications in India.

Steenbrink, Karel., 2007, Catholics in Indonesia, 1808-1942. A documented history. Vol. 2. The Spectacular growth of a self-confidant minority, 19031942. Leiden: KITLV Press.

Tondowidjojo, John, CM., 1995, Menapak Jejak Misionaris Lazaris, Jilid V. Surabaya: Yayasan Sanggar Bina Tama. 